\title{
The Contemporary Significance of the Early Accounting Teaching Methods
}

\author{
ERZSÉBET SZÁSZ \\ Affiliation: Partium Christian University \\ Faculty of Economics and Social Sciences, Oradea, Romania \\ Email: szaszerzsebet@partium.ro \\ EDITH DEBRENTI \\ Affiliation: Partium Christian University \\ Faculty of Economics and Social Sciences, Oradea, Romania \\ Email: debrenti.edit@partium.ro
}

\begin{abstract}
In the light of global trends, economic operators cannot withstand change. At first, computer-driven technologies replaced only routine tasks, which were easily programmed using algorithms. However, as a result of technological development, artificial intelligence, machine learning, the internet and big data, machines have acquired an understanding of non-routine tasks. They have become autonomous, and are now capable of solving more and more complex tasks.
\end{abstract}

The job opportunities offered by the new digitalized world ask for new competencies developed by the education system. Our research examines $20^{\text {th }}$-century teaching methods based on final exams made public, then compares and contrasts them to $21^{\text {st }}$-century teaching materials and examination methods. One of the significant observations is that between 1900 and 1918, the final exam in mathematics contained only word problems. The majority of the 223 problems available, 57 by number, focused on "capital, interest, benefit, loan, sales and purchase." The wording of the problems reflects the (actual) problems and events of the time. Although case studies are still present, most problems are the "calculate, solve, circle, underline" type. Example problems are often provided; thus, problem-solving turns into a routine task. The earlier method yet based on word problems inspired by our everyday economic reality might prove helpful in developing problem-solving skills, in reducing reading comprehension difficulties present at all levels of education as well as in indirectly raising awareness of today's environmental, personal finance, issues.

Keywords: accounting, mathematics, teaching methods, competences, skills 


\section{Introduction}

Global tendencies force every single economic operator to change. At first, technologies controlled by computer systems have only displaced routine production services that could be easily programmed into an algorithm. However, with the development of technology-as a result of artificial intelligence, machine learning, the Internet of Things, and big data-even non-routine tasks and functions have become comprehensible for machines. They have become capable of performing tasks of increasing complexity, also showing the ability of autonomous thinking. As a consequence of this phenomenon, many occupations and fields of activity are jeopardized; so many individuals have to retrain themselves in order to be able to hold their ground in the labor market and possess the personal competencies that convince employers to choose them.

However, the employment opportunities offered by this new, digitalized world require different competencies, developing which is the task of the educational system, teachers, in particular. It is not a simple task, though, since it means meeting requirements that are only partially known or not known at all, while digitalization and automation are happening a lot more quickly than labor market operators, policy, or regulations notice. In addition to this, the new jobs appearing as a result of these processes are also unfamiliar. These phenomena arise in a globalized world in which alarming worldwide occurrences such as pandemic, climate change, or armed conflicts occur. Therefore, education has an outstanding role in developing the skills and competencies individuals need to ensure their sustainability. According to Shear, Gallagher, and Patel (2011), the ability to assume global responsibility is one of the most important competencies of the $21^{\text {st }}$ century. At the same time, improvement of fundamental knowledge, developing certain skills, laying down core values has become more important than ever. In relation to the information revolution, the question of technological dystopia also arises, which can be avoided if the education of the future generations will be marked by the humanities, specifically by arts, empathy, and ethics (Vajna, 2018).

This study offers a short overview of the historical teaching accounting and arithmetic; in addition to this, it aims to present the relationship between these two fields and how teaching these subjects began in Europe and Hungary. As in the case of any branch of science, the books published in the early periods are very important as they may serve as the bases of the teaching material created in the future. The purpose of our research is to highlight the essential elements of teaching accounting and mathematics when these subjects were first introduced in the formal education. These elements may provide useful lessons through a rediscovery of old methods which, if incorporated in the set of modern teaching tools of our days, can render teaching more effective. 
Since studying and teaching mathematics in Hungary started to develop in the $16^{\text {th }}-18^{\text {th }}$ centuries, an overview of the books published in this period is welcome because the content and approaches in these books served as a basis for the elementary-level mathematic textbooks that were later published. One of these outstanding publications is A Kolozsvári Arithmetika, not a mere mathematics textbook as merchants also used it who, thus, had the possibility to study the basic arithmetical operations in their mother tongue. Furthermore, the book is significant from the perspective of the history of science as well because this is the period when the Hungarian mathematical terminology emerged.

As far as accounting is concerned, an overview of a chapter of the $15^{\text {th }}$-century mathematical encyclopedia, the Summa de arithmetica, geometria, proportione et proportionalità. Particularis de computis contains the foundation of today's recording method called double-entry bookkeeping.

In the present research, we also examined the teaching methods of mathematics and accounting at the beginning of the $20^{\text {th }}$ century based on the analysis of mathematics word problems included in secondary-school leaving examination. In addition to this, a Hungarian accounting workbook published at the beginning of the $20^{\text {th }}$ century is also presented.

\section{The science of counting}

To have comprehensive knowledge of any field of science, it is necessary to study both its present level of development and its history in order to gain an overall picture of its origin and future.

In medieval Europe, books were copied by hand. Students learned from the books they copied from their teachers. Copying by hand was replaced by Gutenberg's printing machine; thus, Gutenberg started the mass production of books and textbooks. From the second half of the $15^{\text {th }}$ century, the printing houses in the vicinity of universities and larger school centers in Western Europe specialized in printing textbooks. Some of the first significant publications in the field of mathematics are presented below.

\section{The first European publication in the field of mathematics}

Prosdocimo de Beldomandi ( 1380-1428) was an Italian mathematician born in Padua whose name is linked to the formula of the sum of the geometric progression. His work entitled Algoritmus de Integri appeared in 1410 in Latin. Another significant book was published in 1482 in Bamberg, known as the Bamberg Mathematics, written by Wagner Urlich, arithmetic master from Nürnberg. It was the first printed arithmetic book in German. 
A further mathematician who wrote a book was one of the most outstanding mathematicians of the $15^{\text {th }}$ century. Fra Luca Bartolomeo de Pacioli's (1445-1514) work entitled Summa de arithmetica, geometrica, proportioni et proportionalita, published in 1494 in Venice, puts down on paper almost all mathematical knowledge of its time: Arabic numerals, the four basic mathematical operations, fractions, problems solved with both the simple and the compound rule of three, proportional division, percentage calculation, calculation of interest, product and value of goods calculation, mixing problems, coin and casting calculation. It also mentions the "company rule," "calculation of time limits," and "mixing calculation."

Master György-George Martinuzzi-was the first Hungarian who authored a printed book published in the field of mathematics. The Hungarian monk living the Netherlands finished his book, Arithmeticae Summa Tripartita Magistri Georgij de Hungaria, in Latin in 1499. It was found by Árpád Hellebrant in 1893 in the Hamburg City Library, and it was published again by the Hungarian Academy of Sciences in 1894.

The German mathematician, Adam Riese (1492-1559), was one of the most outstanding arithmetic masters of his age. He introduced the notations in the operations with fractions that are used in our days. His book appeared in 1525 in Erfurt, and although it does not contain original research, it had a long-term effect on the development and spreading of mathematics because it had been formulated with great didactical skills. It contains the theoretical mathematical knowledge of his age, and it has a great structure from a didactical point of view. He focused on advancing from the simple to the complex, repeated every algorithm with new problems again and again-an important principle in the teaching of mathematics to our days (Debrenti, 2016).

Gemma Reinerus Frisius (1508-1555) was a professor of Leuven University, a doctor, and mathematician. His 37-page long work entitled Arithmeticae practicea Metodus facilis appeared in 1540. The book first describes the rules, and then it offers an example to illustrate each one and make practice easier. As a result of his work, the Arabic positional numeral system became widespread in the $17^{\text {th }}$ century, similarly to the pursuit to do the mathematical operations fast and with more routine. Therefore, the teaching of mathematics focuses even more on becoming mechanical.

Simon Stevin (Stevinus) (1548-1620), Dutch mathematician, physicist, and engineer, published his work entitled La disme in 1585, in which he introduced the decimal fractions presenting their practical application as well. 


\section{Hungarian mathematics in the $16-18^{\text {th }}$ century}

In this era, scientific publications were written mostly in Latin. Readers who were somewhat educated but did not know Latin could only read prayer books and calendars. As a consequence, mathematical expressions in Hungarian rarely appear in texts written between $16^{\text {th }}$ and $17^{\text {th }}$ centuries, and there is no continuous text in Hungarian left behind (Keresztesi, 1935). Hungarian mathematics started to take shape in the $16-18^{\text {th }}$ centuries as the authors strived to create a Hungarian scientific terminology for mathematics and reserve certain words of the language for the field of mathematics. Since it contains many symbols and signs, mathematical terminology is different from the terminology of other fields. The books that appeared in this period are very important from the perspective of science, as the teaching materials and didactic considerations included in these served as a basis for the elementary-level mathematic textbooks that appeared later on (Debrenti, 2016).

Six important works were published in Hungarian until the 1777 educational reform introduced by Maria Theresa, whose decree promoting Germanisation hindered education in Hungarian that had just slowly started to set off. Empress Maria Theresa's decree issued on August 22, 1777, the I. Ratio Educationis, made teaching mathematics compulsory an hour a week in the second grade of schools with education in the mother tongue. The Ratio Educationis II of 1806 made teaching mathematics compulsory from first grade already and it also specified the content of the teaching material. It was around this time that the first mathematics textbooks in Hungarian were published.

The printing house in Debrecen founded by Rudolf Hoffhalter in 1561 was the first one to publish a Hungarian arithmetic work, Aritmetica, az az A Számve Tesnec Tudomania [Arithmetic, or the Science of Counting] in 1577. Its author is anonymous, for this reason it is known as the Debreceni Arithmetika. Its revised version, Kolozsvári Arithmetika, appeared in 1591. The work entitled Magyar Arithmetika, az az számvetésnek tudománya [Hungarian Arithmetic, or the Science of Counting] is the property of the Scientific Collection of the Reformed College from Sárospatak and it was published in "Colosvarat, 1591" [Cluj Napoca]. The books published in this period are characterized by poor vocabulary (Keresztesi, 1935).

János Apáczai Csere's (1625-1659) comprehensive work, Magyar Encyclopaedia [Hungarian Encyclopaedia], was the first Hungarian encyclopaedia. It was published in 1655 in Utrecht despite the title page indicating 1653 as the date of publication.

\footnotetext{
${ }^{1}$ Due to the modern technology of our days, the book, together with many other valuable works, is now accessible. It has been digitized by the Hungarian Institute of the History of Science headed by the historian of science István Gazda, the director of the Institute.
} 
Ferenc Menyői Tolvaj (?-1710) penned Az arithmetikának, avagy a számlálásnak ot speciesinek rövid magyar regulákban foglaltatott mestersége [The short rules of the art of arithmetic or counting in Hungarian] in 1675 (Menyői Tolvaj, 1675).

In the $18^{\text {th }}$ century Arithmetic is still taught according to Adam Riese's curriculum, with decimal fractions being included. However, due to the influence of Bracon, Locke, Ratka, and Comenius, the methodology changed a lot.

In 1738, at the age of 23, György Maróthi (1715-1744) became teacher at the Debrecen College, and through his reforms he transformed the school in seven years. He was the one who wrote the first Hungarian textbook in the field of arithmetic, Arithmetika vagy számvetésnek mestersége [Arithmetic, or the art of counting], in 1743. A sample of his work can be found in the Archives of the Franciscan Parish of Gyöngyös-Alsóváros (see Figure 1). He introduces Hungarian terms for various mathematical expressions. For example, "Kalmárok Regulája" ["Rule of Merchants"] originated from the Latin designations Regula Detri or Regula Trium. Maróthi introduced the Hungarian name "egyszerú hármasszabály" (simple rule of three), which means that we always seek the fourth number based on three known numbers (Maróthi, 1743). He used this designation to calculate direct and inverse proportionality problems as well. Another term that he presented and explained was the "company rule": when establishing a company, merchants give a sum of money for public trading; when that money brings some profit or a deficit occurs, the amount everyone gets from the profit should be decided based on the Company Regula (Debrenti, Kolozsvár Arithmetics, 2016).

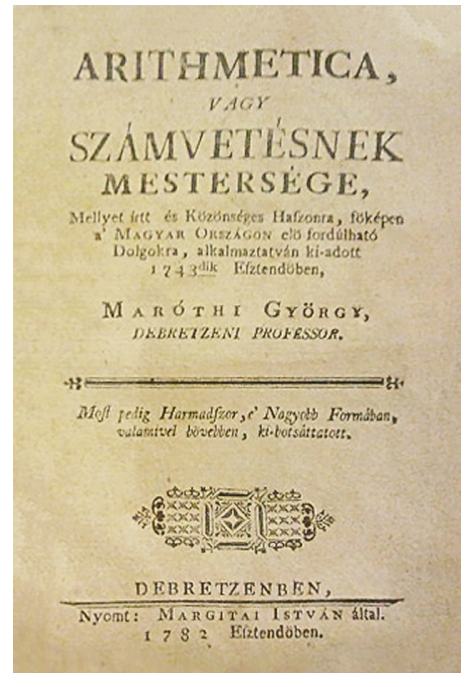

\section{Figure 1}

The first Hungarian textbook by Maróthi György

Source: the Library Archives of the Franciscan Paris of Alsóváros in Gyöngyös (Gyöngyösi-Alsóvárosi Ferences Plébánia Műemlékkönyvtára) 


\section{The analysis of the Kolozsvári Arithmetika or What did a merchant learn in the past?}

The significance of Debreceni Arithmetika, considered the first Hungarian mathematics textbook, is unquestionable as some of the expressions it started to use in the field of arithmetic had not been used in a mathematical context before. Its second edition, Kolozsvári Arithmetika, is more complex than the first edition. It is the basis for most subsequent arithmetic textbooks, in addition to contributing to the development of Hungarian arithmetic terminology. It was more than a school textbook as merchants also used it to study the basic mathematical operations in their mother tongue. The title page (Figure 2) gives us more insight into the book's content, purpose, and what it could be used for ${ }^{2}$. The title suggests that this publication is the revised and extended edition of the Debreceni Arithmetika enriched with several new and useful examples ${ }^{3}$. The engraving on the title page illustrates the interior of a merchant's shop, which could be interpreted as a hint at the target group of the book. The text aims to present a quick and useful method of counting, which is very easy to learn, for those interested in the field of counting (Maróthi, 1743). Ö. Kovács believed that the anonymous author of the book mastered the language well because his way of thinking, his expressions, his puns have such a wonderful Hungarian character to them, that the mathematical text written in 1591 was far more enjoyable to read than the works of many Hungarian writers those days (1877).

Figure 2

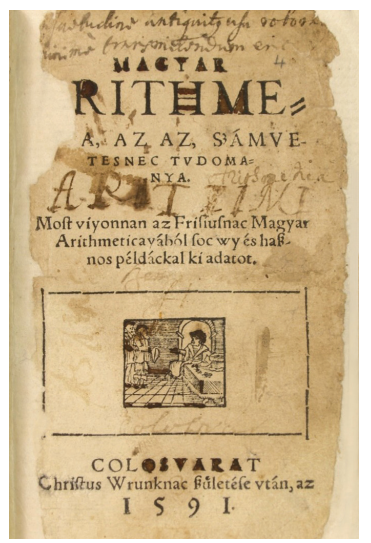

Kolozsvári Arithmetika

Source of Figure 2

and Figure 3:

The Scientific

Collection of the

Reformed College

from Sárospatak

(Sárospataki

Református Kollégium

Tudományos

Gyűjteménye)

The engraving illustrating the inside of a merchant's shop
Figure 3

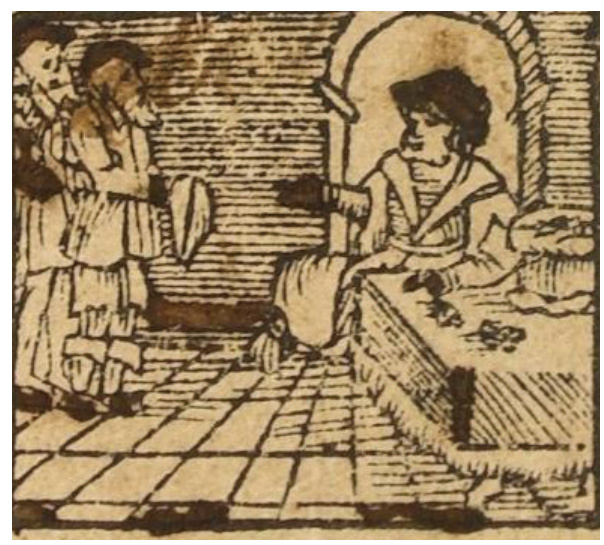

2 "The science of Hungarian Arithmetic or Counting. Published recently based on the Hungarian Arithmetic of Frisius with many new and useful examples in Kolozsvár in 1591 after the birth of our Lord Christ."

${ }^{3}$ Ödön Kovács (1877) believes that despite what the title page suggests, this book was not the new and extended edition of the arithmetic of the Hungarian Frisius printed in 1577 in Debrecen and published again in 1582. The length, the editing, the rules, the explanation of the operations, the examples in the book all diverge from the Debrecen model; only a few elements remind us of the Hungarian Frisius. The author makes many references to the old "Hungarian Mathematical Book," occasionally expressing his harsh criticism of it. Comparing the two works, he claims that the author from Kolozsvár was a better mathematician than the one from Debrecen. 
When assessing textbooks, there are two main functions to be emphasized: how the knowledge presented in the book can be acquired and the purpose of the book reflected in the tasks presented in the textbook. Based on Fischerné Dárdai's (2008) criteria, textbooks are analysed as follows: a) the subject matter, the topics; b) the questions and problems; c) the learnability of the technical terms; d) the illustrations, bibliographical aspects.

\section{The topics of the book}

The book consists of two main parts; the first part presents the mathematical operations with many practical applications, each amended with explanation. Figure 4 illustrates the multiplication table called the Heltai multiplication table instead of Tabula Pythagorica-the Hungarian name is used instead of the international one. The subsequent sections present four rules: Regula Detri, simple rule of three, Regula Vulgaris, complex rule of three which is traced back to the simple rule of three, Regula Societatis, the company rule, and Regula Falsi, solving linear equations with planned trial.

\section{Figure 4}

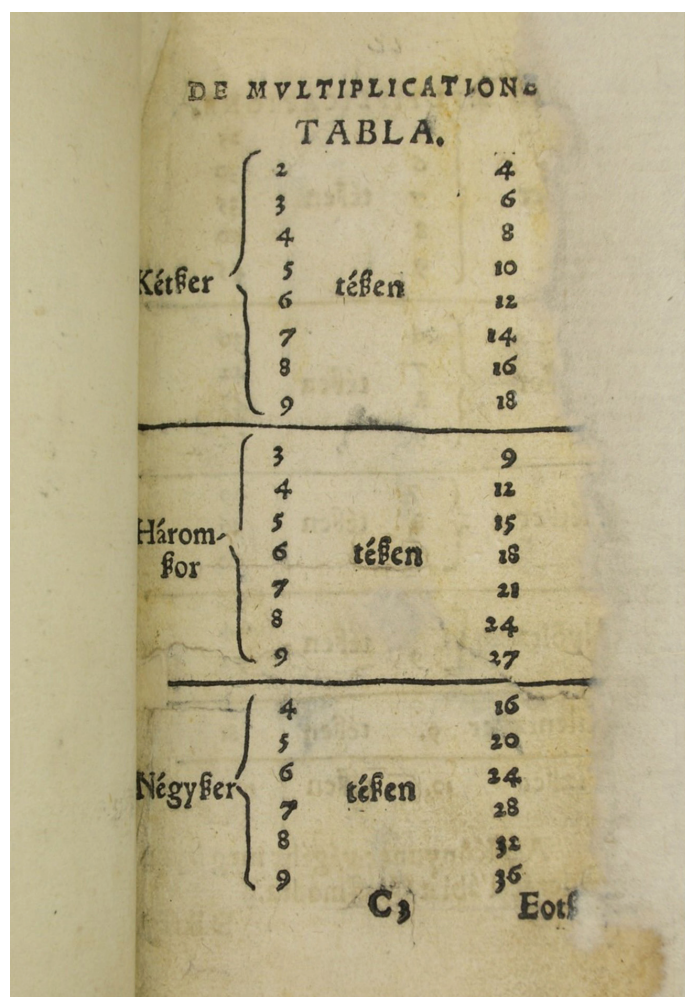

Multiplication table

Source: The Scientific Collection of the Reformed College from Sárospatak (Sárospataki Református Kollégium Tudományos Gyűjteménye) 


\section{Questions and problems}

The problems in the book were very practical and each problem was explained (Table 1). It does not contain any number problem; for every operation and rule, only word problems are formulated. Separating word problems from number problems was not customary at that time.

\section{Table 1}

The proportion of number problems and word problems in Kolozsvári Arithmetika

\begin{tabular}{ll}
\hline Description & Value \\
\hline Number of problems (pieces) & 120 \\
The proportion of number problems (in \%) & 5 (these contain text and explanations as well, \\
& but these are instructions rather) \\
The proportion of word problems (in \%) & 95 \\
\hline
\end{tabular}

The content of the word problems illustrates the author's perception of children typical of that age, also showing the dominant world view and value system of the era. The topics of problems relate to every-day concerns like respecting private property, and refer to moral characteristics such as honesty, helpfulness, and patriotism. Topics also include elements of everyday life, for example, professions, buildings, parts of buildings, means of payment, relationships, partners, connections, animals, plants, places, objects, clothes, food, and drink.

\section{The learnability of the pedagogical texts and the usage of technical terms}

Usually, problems of understanding and learning are mostly caused by technical terms. The frequency of technical terms largely influences the comprehensibility and learnability of a text.

\section{Table 2}

The occurrence of technical terms in Kolozsvári Arithmetika

\begin{tabular}{ll}
\hline Description & Value \\
\hline Number of pages & 256 \\
Number of technical terms & 1266 \\
Number of technical terms per page & 5 \\
\hline
\end{tabular}


The average sentence has 35-40 words, and around three of them are technical terms. The shortest sentence contains ten words, while the longest contains 54. As opposed to this, textbooks today have 1-3 word long sentences, and are characterized by the use of undeveloped codes (Köves, 2010).

The author aimed to make his work readable and easy to understand; to achieve this, he introduced a few punch lines in the text, which is very rare nowadays in textbooks with a similar topic. The punch lines are characteristic of the age. In one of the examples, Maróthi illustrates the length of addition if that involves many items, by comparing it to the time it takes to fry an egg (1743). In another example, to illustrate how expensive an item is, the author claims that the long-distance transport fee is yet to be included in the price (Maróthi, 1743). In connection with one of the rules, he writes that the rule in question has no use whatsoever in Hungary because it cannot be applied due to Hungarian people's nature. Also, he justifies the name of Regula falsi-the false position method-with humor as he claims that it is not called false because it teaches false things.

The author believes that it is important to learn, use and understand technical terms in Hungarian. He uses terminology extensively, in some cases he uses more technical terms for one notion. Thus, the vocabulary of notions found in the book is diverse.

\section{Illustrations, bibliographical aspects}

Illustrations play a significant role in understanding and remembering the information to be learned. They can be examined from three aspects: quantity, type, and whether they correspond to the mathematical content. The frequency and classification of the illustrations found in the Kolozsvári Arithmerika are summed up in Table 3.

\section{Table 3}

The frequency and classification of illustrations

\begin{tabular}{lc}
\hline Description & Value \\
\hline The overall number of illustrations & 240 \\
Illustrations for the explanation of the solution for Problems/Examples/Operations & 237 \\
Pictorial illustrations & 3 \\
Average number of illustrations on one page & 1 \\
Illustrations with textual elements & 237 \\
Illustrations without textual elements & 3 \\
\hline
\end{tabular}


Illustrations appear on almost every page, except the summary at the end of the book. The presentation of progressions section contains the largest number of illustrations. These are black and white like the letters. Every problem is illustrated by an image closely related to its mathematical content to guide comprehension (Figure 5). The text of problems and the illustrations form a whole as they allude to each other and solution, in many cases, is aided by guided observation.

\section{Figure 5}

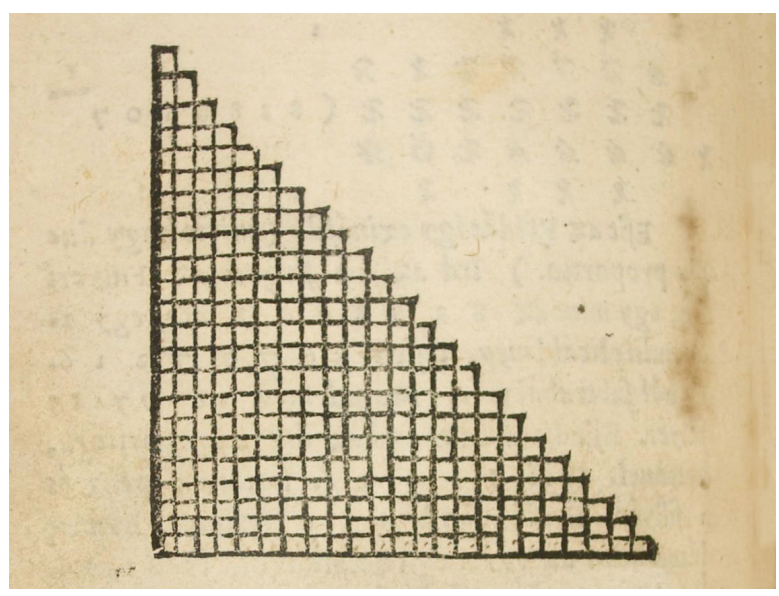

Illustration without textual elements for an easier comprehension of progressions

Source: The Scientific Collection of the Reformed College from Sárospatak (Sárospataki Református Kollégium Tudományos Gyűjteménye)

\section{The science of accounting The first appearance of the double-entry accounting system}

Accounting is connected to arithmetic-or counting, as originally termed-in several aspects. Thus, it is not surprising that the writing in which the double-entry accounting system first appeared was not an economics book with economic content, but the 1494 mathematical encyclopedia entitled Summa de arithmetica, geometria, proportione et proportionalità, published by the Italian friar Luca Pacioli, one of the most outstanding mathematicians of the $15^{\text {th }}$ century. Though this work is regarded as the first book to present a uniform summary of double-entry bookkeeping, the first study describing the double-entry accounting system was published in 1458 and it was written by the Italian businessman Benedetto Cotrugli (Sangster \& Rossi, 2018).

\footnotetext{
${ }^{4}$ The mistake stems from the fact that Benedetto Cotrugli's book entitled Libro de l'Arte dela mercatura was published only in 1573, 115 years after the appearance of his study. In this work, he deals with the double-entry accounting system in only one chapter but does not describe the method in detail. Luca Pacioli refers to this study and gives a summary of the accounting method based on it.
} 
In a relatively short chapter of only 27 pages or 2400 words of his above-mentioned work-a chapter entitled Particularis de computis-Luca Pacioli explains the method to record tradesmen's transactions, wealth, and achievements, which is currently called double-entry bookkeeping. Therefore, the process originates from him ${ }^{5}$. The accounting chapter was translated into many languages, such as English, French, German, Dutch, and Italian. Due to book printing, the Accounting method from Venice became a standard throughout Europe (Gleeson-White, 2013). Since this system lacked notions like the balance and the various criteria for classifying accounts, Baricz (2008) believes that this work cannot be regarded as the basis of description of wealth in accounting.

The $16^{\text {th }}$ century is of crucial importance for accountants, as flourishing trade had created a great demand for this profession. The first modern balance sheet, the Fugger balance, is created in Augsburg in 1511. In the records of the chief accountant educated in Venice, Matthäus Schwarz, nominal ledgers are classified for the first time: he called the book of debts "book of persons' account," while the nominal book of accounts was entitled "Capus." He also had a "little book of expenses" for the expenses and consumption duties, and created a "secret book," which, among others, contained the profit and loss accounts (Sinka, 2014).

The first noteworthy accounting textbook, published in 1592, is associated with another mathematician, Sartorius.

\section{The analysis of Particularis de computis}

Luca Pacioli's description of the basis of the double-entry accounting system from the $15^{\text {th }}$ century is close to the way we are using it today. Pacioli's description is not as detailed as double-accounting system is today, with elaborated standards for every little difference, but it contained every essential element. According to him, in trade three elements are needed: cash, a good accountant, and settling the transactions with regularity so that it may be clear at first glance with through the debit $^{6}$ and credit accounting techniques. He emphasized that regular, systematic accounting is the key to every businessman's peace of mind. Christian faith was

${ }^{5}$ There is earlier evidence of the existence of the double-entry accounting system, for example, general ledgers from Genoa from 1340.

${ }^{6}$ Debit-stems from the Latin word debere, which means: to possess. Credit-comes from the word credere, meaning: to believe. 
inseparable from trading according to the mathematician-accountant-friar; this is why he advised every businessman to offer his record-keeping book to God.?

Pacioli aimed to present and teach to his students-most of them were the children of merchants, who wanted to prepare their successors for business activitiesprocedures that would help them find everything at first glance. He warned that without these elements, both them and their business would get into trouble, so he emphasized the paramount importance of order in doing business.

According to Pacioli, every merchant's purpose is to realize lawful and fair profit and maintain their business. Neither of these targets was trivial at that time as merchants did not have the tools we have today to calculate profit. Keeping an accurate and regularly updated accounting record is the prerequisite for realizing the lawful and fair profit Pacioli mentioned.

\section{The basics of the double-entry accounting method}

According to the system designed by Pacioli, the first step to achieve this purpose is taking an inventory of every possession-both the highly valuable ones and those that seemed insignificant. It had to be completed in one day if possible, and done with accuracy to avoid confusion. The assets taken stock of had to be noted on a separate sheet of paper.

After the inventory is taken, three books are needed to record transactions:

1. A reminder (memorandum) (memoriale) contained the record of every transaction on an hourly basis. Every single item that was bought or sold was mentioned here together with every small detail that might be useful later on.

2. A journal (giornale) helped clarify and organize the data recorded in the memorandum. Every note had to start with one of the following expressions: per-signaling the source, debit ledger account-or to-signaling the target, credit ledger account.

3. A general ledger (quaderno) that consisted of pages divided into two columns. Every journal entry had to be recorded here twice: once in the column on the left side (debit/debt) and once in the column on the right side (credit/demand). The two sides had to be of equal size, to eliminate mistakes.

\footnotetext{
${ }^{7}$ His advice includes that every record-keeping book should be started with the name of God. His holy name should be constantly in the merchants' minds, and the first book should be marked by the holy sign of the cross. This could mean protection but also the implementation of Christian values in business transactions.
} 
Since different currency was used in every large city, the accountant, who kept these records, had to be informed what currency to use for the settlement of the operations. After recording transactions, the books could be authenticated and stamped. Therefore, they became certified, and could be presented in a courtroom (Gleeson-White, 2013, p. 97-100).

As noted above, the accounting technique developed by Luca Pacioli contained every important element of the contemporary double-entry bookkeeping: journal and ledger entry recording, journals and nominal ledgers, allocation, credit/debit, transactions recorded in two accounts, balance equality, inventories, and authentication. In the Pacioli-system, assets are reported on a given date, while results for a period. When compiling the records, the principles to be observed are accuracy, regularity, precaution, legality, fairness, morals, and ethics. The core foundations of accounting and economy have not changed. They grew in complexity, the number of required details extended, and the techniques used in proportion with the complexity of the transactions differ. The process evolved from using double entries to applying international standards and from starting a business with the name of God to formulating the code of ethics.

\section{The emergence of accounting in Romania and Hungary}

Luca Pacioli's principles and ideas influenced the works written in the field of accounting in various countries of Europe. However, merchants still kept simple records based on income and expenditure besides the ones about the buyers, debtors, and suppliers or creditors. This method was rediscovered in Western Europe at the beginning of the $19^{\text {th }}$ century. However, the entries of economic transactions of the enterprises still only served to disclose changes in the assets, to demonstrate the stock of the debtors and creditors, and to protect the interests of the owners.

\section{Crucial moments in accountancy education and the accounting profession in Romania}

This was no different in Romania either, where economic-accounting mindset and the establishment of economic schools in greater cities emerged at the end of the $19^{\text {th }}$ century. Theodor Ștefănescu's coursebook entitled Curs de comptabilitate în partidă dublă [Double-entry accounting] was first published in Bucharest in 1874, and it had seven subsequent publications (1874, 1881, 1888, 1896, 1901, 1902, and 1908). The first publication in the field of accounting dealing with the double-entry accounting 
method was published in Iași in 1901. The author, Constantin Petrescu8 (1858-1902), a prominent figure of Romanian society, practiced and taught the science of accounting. His only work, the 561-page book, published in the field of accounting, Contabilitate şi administrație [Accounting and Administration], is a comprehensive piece that presents all the knowledge considered valuable in the field of bookkeeping in those times, domestic achievements, and his work, his creations, (C.E.C.C.A.R., 2006).

The proposals for the new accounting techniques were further developed by Grigore L. Trancu-laşi (1874-1940). His textbook entitled Curs de comerț și contabilitate [Business and Accounting Course Book] (1914) was published in three editions $(1914,1920)$. It contained the description of accounting of many sectors such as the bank sector, insurances, agriculture, industry, traffic. Through his activity, he became an outstanding figure in the field of accounting in Romania. It is at the beginning of the $20^{\text {th }}$ century that accounting as a profession emerged. The crucial moment of the accounting profession in Romania was October 29, 1921, when an accounting board ${ }^{9}$ consisting of four-hundred members was established. The members were registered in the Corporate Board in three categories: trainees, auditors, and qualified accountants.

Accounting adapts to the given economic-social circumstances and reflects underlying economic, social and other contextual transformations, so during socialism-starting from as early as 1949-normative accounting was introduced for companies. Unified account plans were enforced, balance sheets had to be suitable for every sector of the national economy, and the accounting methodology of transactions followed the principles of the centralized socialist economy. The Board of Auditors and Qualified Accountants, established in 1921, did not meet the requirements of the socialist economy, therefore, it was dissolved in 1951, which left the activity of auditors without any legal framework. However, six years later, this was corrected when they reestablished the status of accounting expert (C.E.C.C.A.R., 2011).

\footnotetext{
${ }^{8}$ Scholar and teacher Petrescu speaks French, German, and Italian, which allows him to have a great insight into the scientific literature of his time. His book contains knowledge and thoughts in the field of accounting from authors like the German Rothschild and Schmidt, the Italian Tonizig, Fr. Villa, F. Besta, Vincenzo Gitti, Giovani Massa and Giuseppe Cerboni, the English Morisson, the French Adolphe Guilbault, Courcelle Seneuil, Hippolyte Vannier, Joseph Barré, Barillot, Augier, Monginot, Henri Lefevre and Eugène Léautey (C.E.C.C.A.R., 2006).

${ }^{9}$ It was made possible by the adoption of Law 80/1921 about the establishment of the 'Board of Auditors and Qualified Accountants'.
} 


\section{The beginning of teaching accountancy in Hungary}

In Hungary, bookkeeping was taught from the middle of the $15^{\text {th }}$ century in the German schools of the mining towns, while organized training in bookkeeping is over 300 years old. In the first bookkeeping college in Europe, Collegium Scientiarum Politico Oeconomico Cameralium, founded by Piarist teacher Valero Jakab in Szempc in 1763, public accounting and economics were already part of the curriculum (Halkovics, 1999).

As mentioned in the chapter on teaching mathematics, Maria Theresa's 1777 decree, the Ratio Educationis, turned mathematics into a compulsory school subject. The first national educational reform in accounting is also related to this decree, as it introduced bookkeeping as part of the high school curriculum in mathematics.

Modern vocational education in commerce started in 1830, and bookkeeping was present in the curriculum many hours a week to assure that students deepen the acquired knowledge. Between 1884 and 1895, 26 commercial schools were opened in Hungary. In these commercial high schools during the three-year training, bookkeeping was taught three times a week in the second and third years. Then, starting from the $1919 / 20$ school year, commercial high-school education was extended to four-year training, and learners did this subject from the second year of their training, three hours a week in the second and third year, and four times a week in the fourth year of their training. (Balázsiné Farkas, 2017).

The year 1959 is considered to be a turning point in the vocational training of bookkeeping. The length of the courses was determined by an order from the Ministry of Finance. Based on this, various qualification degrees could be acquired in the field of accounting: qualified accountant, certified public accountant, qualified auditor, and accountant in the public sector. The exams had to be taken in front of the Számviteli Képesítő Bizottság [Accounting Qualification Committee]. The administrative tasks related to the committee's activity were fulfilled by the Pénzügyminisztérium Könyvviteli Tanulmányi Felügyelősége [Accounting Educational Inspectorate of the Ministry of Finance]. The training was of a high standard and set the foundations for the professional recognition and acceptance of some qualifications (Balázsiné Farkas, 2017).

Another milestone in teaching accountancy in Hungary was the first half of the $20^{\text {th }}$ century when Dr. István Lautenburg was a professor of the Budapesti Kereskedelmi Akadémia [Budapest Commercial Academy]. In 1929 he published the textbook entitled Kettős könyvvitel és mérlegkészítés [Double entry accounting and drawing up balance sheets] and its annex, the "Könyvviteli példatár" [Sample problems in accounting] (Figure 6). 


\section{KÖNYVVITELI}

PÉLDATÁR

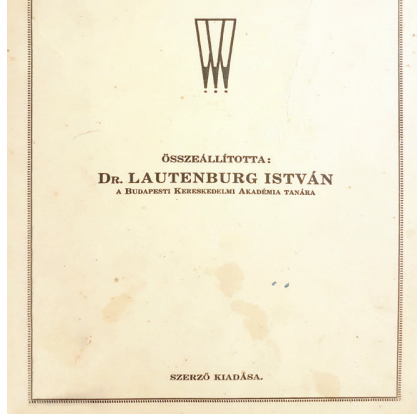

ELöszó.

Könyvviteli tankönyvet példatár nélkül el sem tudunk pzelni, sőt sokan tartják a kơnyvviteltanitás szempontjaból fontosabbnak a példatárt, mint magát a tankönyvet. A jelen példatárt "Kettớs kőnyvvitel és mérleg készítés" cimú kōnyvem függelékének szántam. A felaa gyakorlati életben mükodoo, volt tanitványaim.

Nagyon kérem azokat az igen tiszzelt Kartársolet, akik a példatárt bevezetésre méltatják, hogy annak használhatóságára esetleges hibáira vonatkozó megiegrzóseike velem közölni szivesek legyenek.

Budapest, 1929. szeptember ho.

Dr. Lautenburg István

The preface reveals an author who pursued his profession as a vocation and related to his colleagues with humility and honesty: "I kindly request my honorable Colleagues, who shall review this book of sample problems for introduction, to kindly share with me all their observations regarding any possible mistakes or remarks related to its usability" (Figure 7, my translation). The sample problems are extensive: they contain accounting samples for one month/two months, split accounting and undivided accounting, commission sale with the bookkeeping of the consigner/commissioner, and final statements-in the case of sole traders, limited partnerships, cooperatives, public limited liability companies, general partnerships, and banks. The problems are complex and require knowledge in multiple domains: stock movements, down payment, trade allowances, discount, securities, turnover taxes, consumer rebate, customs duty, currency exchange, credit, commissioner, discounting, personnel salaries, depreciation, and so forth (see Figures 8.1-8.4, Business plan 7). The book of sample problems does not contain short, sample problems, but complex case studies.

As far as accounting regulation is concerned, the first momentum was the adoption of the 1874 Commercial law that prescribes accounting obligations. The law prescribes the requirements of accountancy, but deals with accounting on a very rudimentary level-it contains mandatory provisions concerning individuals who pursue commercial transactions as a profession. Later, introduced by the Law on limited liability companies, the notion of qualified auditor appeared in 1930. The first autonomous act on accounting was adopted in 1968, and it was framework legislation that authorized the Minister of Finance to establish the detailed rules ${ }^{10}$ (Fogarasi, 2011).

\footnotetext{
${ }^{10}$ Starting from 1949, the advisory body of the Ministry of Finance has been the National Accountancy Council
} 


\section{Figure 8.1}

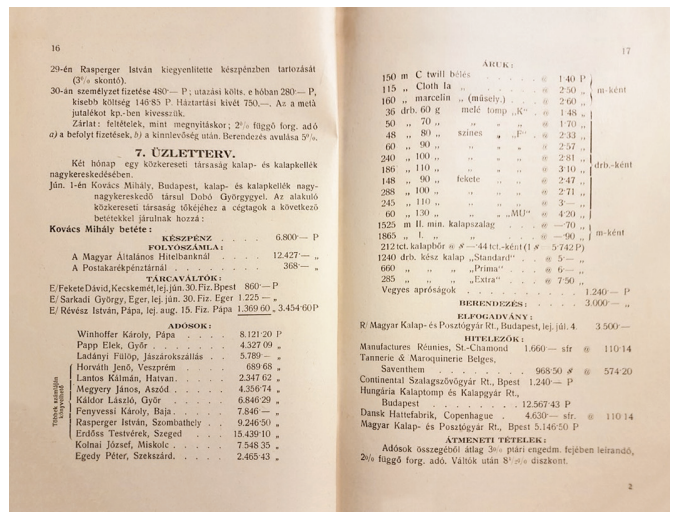

\section{Figure 8.3}

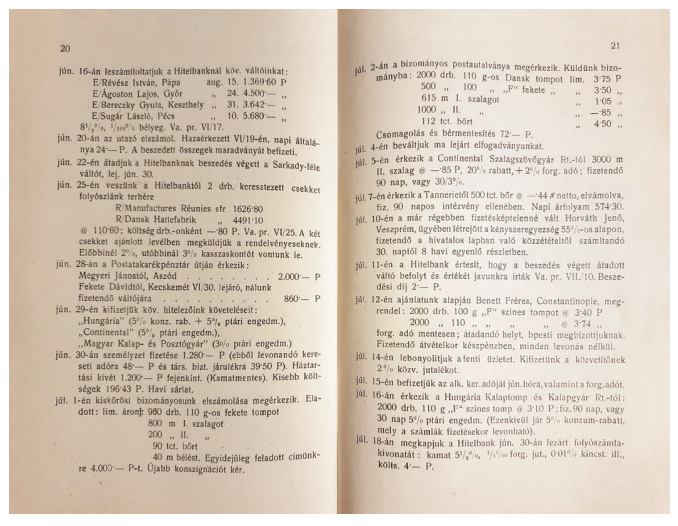

Figure 8.2
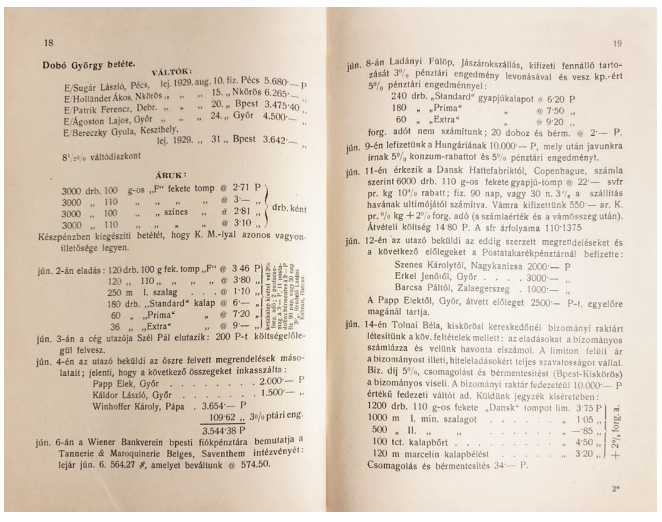

Figure 8.4
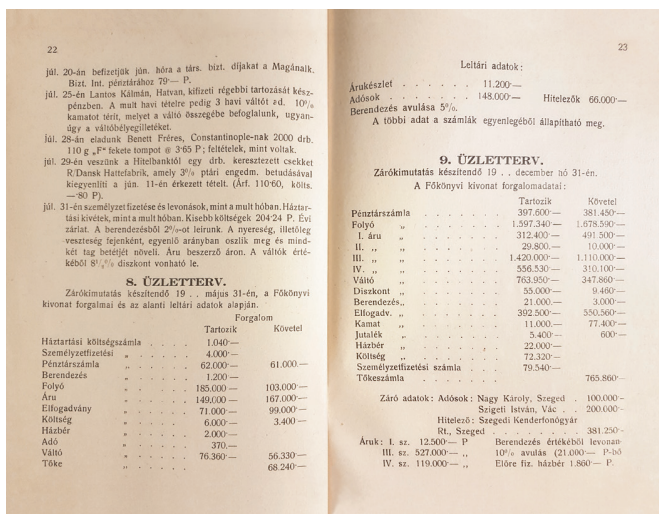

\section{Topics of graduation exam problems in mathematics at the beginning of the $20^{\text {th }}$ century}

Between 1900 and 1918, most of the high schools issued a School Bulletin every year in which they reported every significant event, education, administrative issue. These bulletins also published the names of the students and teachers, their activities, stories, subjects, statistical data, tests from previous year, and other written works. These bulletins were sent to various places, and some of them are available even today. We can find most of these School Bulletins in the Fővárosi Szabó Ervin Könyvtár, Budapest; many of them are accessible electronically (B. Kovács, 2020)11.

${ }^{11}$ https://library.hungaricana.hu/hu/collection/iskolai_ertesitok_helysegnev_szerint/ 
Mathematics was a graduation subject in almost every high school in the years before the 1900s. Based on the available Bulletins, 223 final examination problems have been analyzed (Debrenti, 2020). The following table contains their thematic classification (Table 4):

\section{Table 4}

Thematic classification of graduation problems

\begin{tabular}{lcc}
\hline Theme & Number of & $\%$ \\
& problems & 57 \\
\hline $\begin{array}{l}\text { Capital, interest, allowance, loan, sale-purchase, } \\
\text { problems solved by calculations }\end{array}$ & 25.56 \\
Field measurement, distances, angles, trigonometry problems & 35 & 15.7 \\
Spatial geometry problems: related to geometric solids and spheres & 34 & 15.25 \\
Problems related to triangles, quadrangles, pentagons, hexagons, circles & 23 & 10.31 \\
The application of progressions in problems & 18 & 8.07 \\
Equation, systems of equation & 12 & 5.38 \\
Word problems with equations & 11 & 4.93 \\
Distance, time, velocity & 11 & 4.93 \\
Distance on the globe & 10 & 4.49 \\
The power of binomials and its application & 4 & 1.79 \\
Circle, ellipse, hyperbola & 3 \\
Mathematical analysis (derivation, integration) & 3 \\
Physics (weight, density, diving, power, etc.) & 3 & 1.35 \\
\hline In total & 223 & 1.35
\end{tabular}

Between 1900 and 1918, the mathematical graduation problems were only word problems. Of the 223 problems available, 57 were on the topic of capital, allowance, credit, sale-purchase. The formulation of the problems reflects the relevant issues and events of the age. One of the questions focused on the capital needed throughout the 200-year existence of the school to cover the 180,000-corona maintenance costs, taking into account the $4 \%$ yearly interests of the accumulated capital, and the $3 \%$ mid-term capitalization interests (Paál, 1917, p. 62).

Although case studies are still present in teaching today most problems contain instructions such as calculate, solve, circle, and underline. In many cases sample problems are used, therefore, solving problems has become more of a routine. In order to reduce text comprehension difficulties, present on every level of the educational 
system, and develop problem-solving skills, using the earlier yet still contemporary method-built on word problems inspired by the everyday economic reality-should be used. This approach requires the use the learned formulas, and it also draws attention to other relevant personal or global problems-for example, environmental pollution, sustainability, personal finances-making the students sensitive to these.

\section{Conclusion}

Teaching accountancy has evolved from book copying to digitalization, from the Kolozsvári Arithmerika to the electronic resources, from Luca Pacioli to the International Accounting Standards. There were efforts to do counting operations fast and with more routine as far back as the $17^{\text {th }}$ century. Professions, and jobs built on automatic, routine tasks have become increasingly automatic. This happens so fast that not even labor market operators notice them in time, let alone policymakers. The publications of the first mathematical textbooks and the introduction of teaching double-entry accounting conformed to the requirements created by flourishing commerce, most of the students were active in the commercial sector. Quick and skillful counting was necessary just like the competent calculation of interest, currency, and unit conversion. In Hungary, the calculation of interest, the definition of the average time limit and average interest rate, calculation of debt, discounting of securities, and other operations related to securities were taught in the third grade already the beginning of the 1900s (Könyvtár, 2021). In the seventh grade, in mathematics classes, students could learn about arithmetic and geometric progressions and their applications in the calculation of compound interest, allowance, and repayable loans. Therefore, it is understandable that most of the graduation problems were word problems, which demonstrates a practical approach in mathematical education. The application of theoretical knowledge to solving real-life problems in relevant situations proves that learning was not merely an automatic process. The purpose was to teach the basic operations and develop the notion of these operations through practice. The sample problems were practical, augmented with many explanations, and number problems were absent from the book. The content of word problems reflects the dominant world view and value system of the era. The word problems were inspired by issues relevant at that time, like respecting property, reference to moral characteristics such as honesty, helpfulness, and patriotism. The elements of everyday life are also present. To make these texts readable and easy to understand, the author inserted a few punch lines, which is rare nowadays in textbooks with a similar topic. These punchlines may include joking criticism of certain attitudes or remarks about the names of rules. Another advantage of these coursebooks is that every problem was demonstrated by an illustration that was closely related to the mathematical content. 
In the case of the problems, the explanation, the illustration and the guided observations formed a whole to help students solve the problems. In the first accounting textbook, the mathematician author formulated the essential elements of business: cash, a good accountant, and regularity and also applied Christian values. He named realized profit to be legal and fair. Even today, if we respect in accounting the principles and values mentioned above-accuracy, regularity, precaution, legality, and fairness-the rest will be just minor details and techniques. The core of accounting and economy has not changed throughout times, the fields have become more complex, more detailed, and the range of techniques widened. The process has evolved from using double entries to applying international standards and from starting a business with the name of God to formulating the code of ethics.

The palette of our teaching tools has become more varied and ranges from textbooks to new platforms created through the development of technology. However, we should have in mind the content, the reason and the methods used in education. We do not teach merely counting or accounting. If we did, we might risk ending up with results like the Pinto car cost-benefit analysis of Ford Motor Company. In the case of the Pinto car, the safety measures would have cost the company more than 137 million dollars; however, these cost outweighed the benefits, which was estimated at 49.5 million dollars (Shaw \& Barry, 2016). Therefore, it is important to teach more than just numbers, be it mathematics, accounting, or any other subject. The aim should be to illustrate and explain phenomena through the examples and events of the given era in a readable and easy-to-understand language, using instructive humorous style. This is our mission in accounting education.

\section{References}

Balázsiné Farkas, K. (2017). A munkaerőpiac pályakezdő számviteli szakemberekkel szemben támasztott kompetencia követelménye [The requirements of competencies accountants must meet on the labour force market]. PhD dissertation. PTE.

C.E.C.C.A.R. (2006). ALBUM 85 DE ANI de la înfiinţarea Corpului Experţilor Contabili şi Contabililor Autorizaţi din România [85 Yearbook on the foundation of the Body of Chartered Certified Accountants of Romania]. Editura CECCAR.

C.E.C.C.A.R. (2011). Album istoric. Profesia contabilă din anii socialismului [History album: accountancy in the socialism]. CECCAR.

Debrenti, E. (2016). Kolozsvár Arithmetics. In P. Körtesi (Ed.), Proceedings of the History of Mathematics and Teaching of Mathematics Conference (pp. 71-85). Junior Mathematical Society Miskolc.

Fogarasi, E. (2011). A számvitel szabályozásának változásai Magyarországon: Jelenlegi helyzet, lehetséges jövőképek [Changes in accounting in Hungary: Present-day situation, possible future]. Miskolci Egyetem Digitális Raktár és Adattár http://midra. uni-miskolc.hu/document/11027 
Gleeson-White, J. (2013). Double Entry. How the Merchants of Venice Created Modern Finance. W. W. Norton \& Company.

Halkovics, L. (1999). A magyar ipari szakoktatás és statisztikája 1945 előtt [Hungarian vocational education and the related statistics before 1945]. Statisztikai Szemle, 77 (4), 260-273. https://www.ksh.hu/statszemle_archive/1999/1999_04/1999_04_260.pdf https://ceccar.ro/ro/wp-content/uploads/2011/09/107-123.pdf

Keresztesi, M. (1935). A magyar matematikai münyelv története [The history of the Hungarian technical language of mathematics]. Harmathy Nyomdavállalat.

Kojanitz, L. (2004). A pedagógiai szövegek analitikus vizsgálata. A szavak szintje [The analysis of pedagogical texts. The level of words]. Magyar Pedagógia, 4, 429-439.

Könyvtár. (2021). Iskolai Értesítők [School Bulletins]. https://library.hungaricana.hu/hu/ collection/iskolai_ertesitok/

Kovács, B. (2020). Érettségi vizsgálati feladványok az 1900-1918 közötti évekből [Graduation exam tasks from 1900-1918]. MATLAP, 1, 15-17.

Kovács, Ö. (1877). Az 1591-dik évi Kolozsvári Arithmetika [The Kolozsvári Arithmetika of 1591]. Müegyetemi Lapok, 26-29.

Köves, G. (2010). Mi is az a tankönyv? [What is a textbook?]. KRE-TFK Jubileumi Évkönyv. Opál Bt.

Menyői Tolvaj, F. (1675). Az aritmetikának, avagy a számlálásnak ot speciesinek rövid magyar regulákban foglaltatott mestersége [The craft of arithmetics, or the science of counting formulated through short Hungarian rules]. Karancsi György. http://mek. oszk.hu/15900/15970

Paál, G. (Ed.). (1918). A marosvásárhelyi Református Kollégium államilag segélyezett főgimnáziumának és elemi iskolájának értesítője az 1917-1918-ik iskolai évről [The school bulletin of the Reformed College of Târgu Mureș: 1917-1918]. 17. Marosvásárhelyi Református Kollégium előljárósága.

Sangster, A., \& Rossi, F. (2018). BENEDETTO COTRUGLI on double entry bookkeeping. De Computis, Revista Española de Historia de la Contabilidad, 15(2), 22-38.

Shaw, W. H., \& Barry, V. (2016). Moral issues in business. (13th ed.). Centgage Learning. Shear, L., Gallagher, L., \& Patel, D. (2011, November). ITL Research. Microsoft Partners in Learning. Retrieved may 20, 2021, from: https://www.european-agency.org/sites/ default/files/itlresearh2011findings.pdf?fbclid=IWAR3VK28KJWVAKOPIN85Igl4tY79n7UAGKbvHimlvFc86MBTt2KnVo83×29o

Sinka, J. (January 01, 2014). Mérlegen a középkor [Balancing the Middle Ages]. Retrieved 04. 05, 2021, from Adózóna: https://adozona.hu/altalanos/Merlegen_a_ kozepkor_UFF4ML

Vajna, T. (2018, September 17). Vér nélkül lezajlik az információs forradalom, vagy lesznek áldozatai is? [Is the information revolution going to have victims or not?]. Qubit. https://qubit.hu/2018/09/17/ver-nelkul-lezajlik-az-informacios-forradalom-vagylesznek-aldozatai-is 